\title{
A fotografia do vazio - sobre Haruo Ohara
}

\author{
Rodrigo Fontanari' \\ https://orcid.org/0000-0001-8580-3029 \\ I - Unicamp. \\ Campinas (SP), Brasil
}

Resumo: Este artigo debruça-se sobre a obra do fotógrafo nipo-brasileiro Haruo Ohara, pouco conhecida entre nós, e que se distingue da de outros fotógrafos pela sua ousada estética que tende a um vazio: captar a presença das coisas e não seu sentido. Sua intensa produção fotográfica é estranhamente realizada em paralelo a sua atividade de agricultor. Ohara cria instantes de "espaços vazios" de acontecimento que atestam um estado de pura contemplação, em que o fotógrafo dá a ver ao espectador simplesmente a poesia das formas. O estilo de Ohara tende, por hipótese, àquele princípio de naturalidade zen que distingue a tradicional arte japonesa da paisagem: um nada especial que se refere a um estado de coisas expresso em sua naturalidade. Quer-se aqui enveredar por este caso especial.

Palavras-chave: Haruo Ohara; fotografia de arte; vazio.

Abstract: The photograph of emptiness - on Haruo Ohara - This article focuses on the JapaneseBrazilian photographer Haruo Ohara, little known among us, and who distinguishes himself from other photographers for his daring aesthetics that tends towards an emptiness: it captures the presence of things and not their sense. His intense photographic production is strangely held in parallel to his activity as a farmer. Ohara creates moments of "empty spaces" of happenings, which attest to a state of pure contemplation, in which the photographer gives the viewer simply the poetry of forms. Ohara's style tends, by hypothesis, to that principle of zen naturalness which distinguishes the traditional Japanese art: a nothing especial which refers to a state of things expressed in its naturalness. We here aim to embark on this particular case.

Keywords: Haruo Ohara; art photograph; emptiness.

\section{Agricultor-fotógrafo}

Apresentar a obra fotográfica de Haruo Ohara requer antes que se faça uma breve e pontual incursão à biografia desse agricultor transformado em fotógrafo. 
Passemos a uma apresentação, em grandes linhas, de sua vida. Ohara nasceu numa família japonesa que não temeu se lançar ao mar em 1927, em direção ao Brasil, onde, pouco tempo mais tarde, em 1933, ele e toda sua família fixaram suas raízes numa comunidade nipônica na cidade de Londrina. Foi ali que, pela primeira vez, ele entrou em contato com a fotografia. Mais especificamente, sua aventura fotográfica inicia-se quando ele encontra o fotógrafo local José Juliani' ${ }^{2}$ É Juliani que lhe oferece seu primeiro aparelho fotográfico, e ensina-o a manuseá-lo e a revelar os negativos. Seu primeiro registro fotográfico acontece em 1938, por ocasião de seu casamento, quando decide retratar sua esposa Kô. E dali por diante sua relação com o aparelho fotográfico e suas possibilidades de olhar para o mundo não cessam.

O olhar de Ohara se volta notadamente para aqueles que ama: sua família e seu entorno, dedicando-se também a uma fotografação poética da relação do homem com a natureza. É a partir do ano de 1951, quando então se torna membro fundador do Fotoclube de Londrina e se associa ao Fotoclube Bandeirantes de São Paulo, que sua prática fotográfica vem a público, sendo por várias vezes premiado pela expressividade e qualidade artísticas de suas imagens fotográficas.

Do mesmo modo que o poeta e filósofo têm entre suas mãos o lápis e o papel, Haruo Ohara mantém, entre as suas, as ferramentas agrícolas e o aparelho fotográfico. Ele se divide entre o cultivo e a prática da fotografia com a mesma acuidade. Ohara não parece hesitar a qualquer instante em lançar mão do peso da enxada, do corte seco e preciso do facão e de toda leveza e transparência da peneira - alguns de seus instrumentos de trabalho na lida cotidiana exigida pelo cultivo e pela colheita do café -, por um único aparelho cuja agilidade, velocidade e precisão permite-o cultivar os instantes vividos tanto na lida dura com as plantações de café quanto com seus familiares. Não por acaso, pode-se ousar dizer que Ohara faz com suas fotos verdadeiras geórgicas à japonesa, que celebram a vida campestre e despertam o amor ao campo. Como se sabe, a natureza tem um papel importante na cultura japonesa. Tanto é que os japoneses não "conseguem contemplá-la intelectualmente, analisá-la e recompô-la. Anseiam por adaptar-se a ela e nela se perder", lembra-nos Hans-Joachim Koellreuter (1984, p. 58) em À procura de um mundo sem "vis-à-vis". Reflexões estéticas em torno das artes oriental e ocidental.

Tal como Virgílio nas Geórgicas, Ohara limou com esmero suas imagens da terra, rendendo às artes um trabalho sublime que produz um ponto de inflexão na história recente da fotografia de arte brasileira. Como agricultor, Ohara cultiva a terra. Como fotógrafo, ele cultiva o tempo, diria mesmo o instante. Suas imagens parecem restituir o tempo. Não por acaso, apressa-se a notar Marcos Sá Correia, em A fração de segundo e a história, ensaio de abertura e apresentação do volume Haruo Ohara - fotografías:

1 Juliani chegou em Londrina em 1933. Era um sujeito autodidata, que aprendeu o ofício de fotógrafo numa cidade do interior do Estado de São Paulo, Nova Europa, com um senhor de quem se sabe apenas o apelido, "alemão", e de quem adquiriu o equipamento necessário para se iniciar nessa profissão. Para maiores esclarecimentos, recomenda-se a leitura da biografia de Haruo Ohara, Lavrador de imagens, feita pelas mãos de Marcos Losnak e Rogério Ivano e, mais especificamente, sobre a história da fotografia em Londrina, o artigo de Paulo Celso Boni "A fotografia como mídia visual da recuperação de Londrina", publicado no V Congresso Nacional de História da Mídia. 
ainda bem que Haruo Ohara era amador. Como profissional, dificilmente teria feito o que fez. Os profissionais geralmente têm pressa. Cobrem guerras, festas, posses, revoluções e toda infinidade de compromissos regidos pelas agendas alheias. Seu tempo não lhe pertence. Eles costumam ir muito longe atrás dos mesmos assuntos. E, em casa, descansam a máquina. Haruo Ohara cobria sua vida, à medida que ia vivendo (CORREIA, 2010, p. 10).

O fazer fotográfico se faz no transcorrer do tempo. O fotógrafo é aquele que espreita o tempo - o ritmo do amadurecimento, a pontuação própria dos acontecimentos - e, assim, deixa que cada gesto ou evento se contamine do tempo de que precisa para se efetivar.

\section{Uma arte sem arte}

Cabe começar por apresentar o vazio, tal como é, aqui, entendido. Emprega-se a noção de vazio no sentido budista do termo, que ensina que toda forma é vazia. Isto é, como explica o estudioso do budismo Francisco Handa (1991, p. 53) em seu O que é zen, todo esforço do zen consiste em tentar "ver as coisas como elas são"; "em estado de $m u$ (vazio)". Para usar ainda as mesmas palavras de outro estudioso do budismo, Chögyam Trungpa (1976, p. 182), em La pratique de la voie tibétaine, o que o zen visa a revelar é que "a forma é o que existe antes que projetemos por cima nossos conceitos. É o estado original do 'que está aqui', as qualidades coloridas, vivas, impressionantes, dramáticas, estéticas que existem em todas as situações." E, se aos olhos do budismo ela é vazia, é porque, antes de tudo, "a forma é vazia de nossas ideias preconcebidas, de nossos julgamentos", ou melhor, "a forma é vazia se nós as vemos na ausência de nossas próprias interpretações pessoais" (ibidem, p. 182).

Ora como nos chega do Oriente, a arte japonesa expressa o zen em suas formas, o que quer dizer, noutros termos, que a arte japonesa subsiste a ideia básica do zen. Aliás, o zen, é preciso dizer logo de saída, "não é decididamente um sistema fundado na lógica e na análise. É algo antípoda da lógica e do modo dualista de pensar", escreve Daisetz Teitaro Suzuki (1971, p. 12), professor de filosofia budista da Universidade de Otani, em Kioto no Japão, em Introdução ao zen-budismo. O zen, como preferem compreendê-lo uns e outros, é "um estado de mente em que a tensão dos opostos é reduzida ao silêncio, não tendo sido aniquilada nem exorcizada, negada ou ignorada, mas apenas abandonada", nota o pensador britânico Christmas Humphreys (1977, p. 87), em O zen-budismo.

Trata-se, portanto, de uma experiência individual, imediata, inexprimível, cuja finalidade última é fazer recuar a bifurcação ou a divisão das unidades entre os opostos, conduzindo à "iluminação interior" (em japonês satori). O zen revela-se também na maneira de agir imediatamente antes que haja a intervenção de uma imensa porção de emoções. Isto é, consiste na ação executada no "aqui e agora", imediatamente, sem passar antes pela mediação do gosto ou desgosto, propósito ou desejo. É agir nesse "aqui e agora" e não em seu significado; é também deixar a experiência revelar-se em seu imediatismo. 
Lembro, aqui, por oportuno, que toda minha reflexão em torno da fotografia é devedora da obra de Roland Barthes (2007, p. 98), que tem também estado às voltas com a tradição japonesa do zen, dadas as conhecidas referências da teoria barthesiana a essa tradição, ao vislumbrar nela "uma imensa prática destinada a deter a linguagem", conduzindo-a ao seu "fosco". Ora, tal enfoque parece justificar o presente estudo de caso.

Parte-se de uma ideia corrente de que frequentemente toda arte é uma criação pessoal que tem sua origem numa tradição. Dessa maneira, a proposta é a de colocar a obra fotográfica de Ohara à contraluz do zen na arte japonesa. Isto é, busca-se mostrar como o fotógrafo incorpora o zen à sua arte. Com isso, é possível entrever, nessa arte ocidental, a fotografia, o lado oriental de que se constitui o olhar desse agricultor-fotógrafo e mostrar notadamente como se dá, no plano da imagem, essa "enunciação silenciosa", que consiste em revelar o inexprimível e o mais profundo, aquilo que, dentro do universo budista, pode ser entendido como efemeridade.

Grande parte do acervo fotográfico de Ohara é construído sob o signo do interstício e do vazio, conceitos muitas vezes de difícil apreensão; por não ser fácil traduzi-los verbalmente, são muito mais predicações identificáveis pela experiência sinestésica.

Denomino como interstício esse gesto fotográfico de Haruo Ohara que valoriza os espaços em branco ou os vãos e os espaços vazios ou intervalares das formas que se inscrevem como que naturalmente em seu quadrante fotográfico. Como se o fotógrafo buscasse, estranhamente, uma zona de suspensão, de silêncio que se estabelece no limiar da percepção (aquilo que ressoa como eco no silêncio da pausa). Ponto de suspensão ou de silêncio que valoriza a imagem e abre-a para um além de sua visualidade. Uma respiração, uma aeração que dá forma a esses espaços ditos vazios. Trata-se, dessa maneira, de uma parte que nada contém, no entanto, tudo aí significa.

Penso nesta foto de 1944, "De manhã - Indo para colheita de Café". Enormes espaços vazios nas cenas em que o olhar vagueia nos entre/vãos, permitindo ao espectador viver o momento fotografado. É como se caminhássemos com o olhar junto com o personagem. Ou esta outra, de 1955, "Cafezal de uma propriedade ao amigo" em Londrina. Paisagem plena, porém a ruptura provada pela pilastra divide a cena e produz nela uma confusa ilusão, como se fossem imagens rebatidas que quebram totalmente a dicotomia interior e exterior, e tudo parece se tornar apenas um plano.

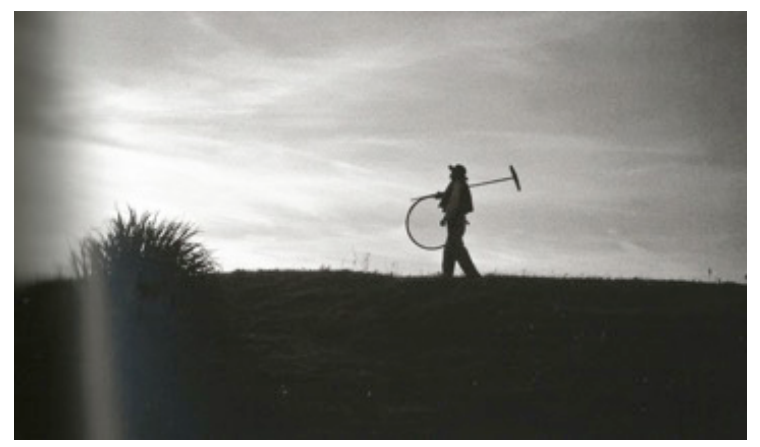

Fig.1. De manhã - Indo para colheita de café Fonte: Instituto Moreira Salles 


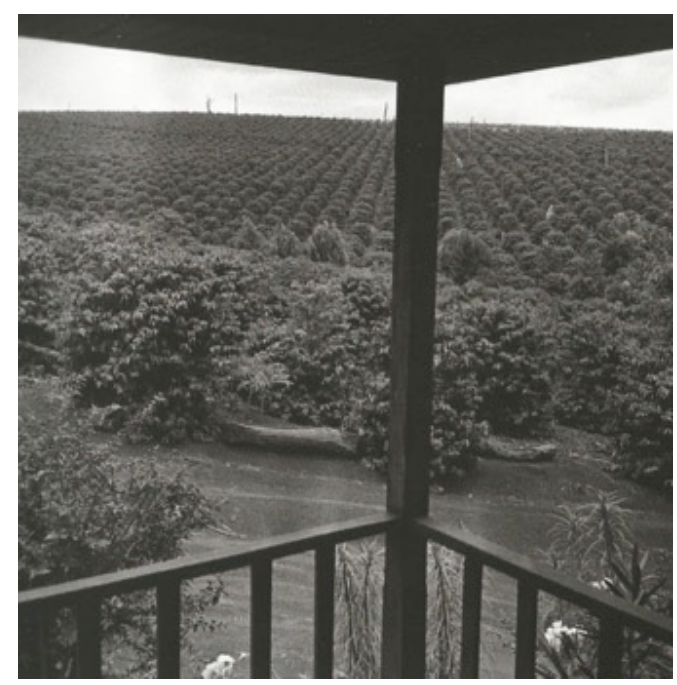

Fig. 2. Cafezal de uma propriedade ao amigo de Londrina Fonte: Instituto Moreira Salles

É ainda Daisetz Susuki (1960, p. 12), numa de suas conferências reunidas no volume Zen-budismo e psicanálise, que começa por lembrar aos leitores ocidentais: "o Oriente é silencioso, ao passo que o Ocidente é eloquente. Mas o silêncio do Oriente não significa apenas ser mudo e permanecer sem palavras ou sem fala. Em inúmeros casos, o silêncio é tão eloquente quanto a verbosidade. O Ocidente aprecia o verbalismo. E não é só isso, o Ocidente transforma a palavra em carne e faz com que essa carnalidade sobressaia, às vezes de maneira demasiada notável, ou melhor, demasiado gritante e voluptuosa, em suas artes e religião".

Nessa concepção zen da arte, ela torna-se não apenas "uma representação da natureza", mas ela mesma "um trabalho da natureza", isto é, a arte da "ausência de arte", como bem expôs o filósofo alemão Eugen Herrigel (1983) em seu breve ensaio $A$ arte cavalheiresca do arqueiro zen. Neste breve e fulgurante ensaio cujas personagens são o mestre, o discípulo, o arco, a flecha e o alvo, o leitor é conduzido à experiência zen, a experimentar a harmonização do consciente e do inconsciente, que o faz agir sem refletir, deliberar, conceptualizar, ou antes mesmo que surja o pensamento.

Essa bela foto intitulada "Crianças apreciando o arco-íris" data de 1950 e mostra que o fotógrafo soube esperar o trabalho da natureza, contemplar suas formas de aparição, que silenciou até mesmo os espíritos mais irrequietos: as crianças.

Ou então, esta outra foto de 1955, intitulada "Maria, filha de Haruo e Maria Tomita, sobrinha" no Sítio Tomita, em Londrina, em que se vê o trabalho da contemplação do fotógrafo que disparou seu gatilho no segundo exato em que o corpo não é mais apenas um peso que se projeta gravitacionalmente em direção ao chão, mas um corpo pouco denso que parece levitar a alguns metros desse chão sem perder sua graciosidade. 
Como faz saber Michael Lucken (2001, p. 50), evocando as notas do antigo presidente do Museu Nacional de Arte Moderna de Kyoto, Kawata Michiaki, no preâmbulo de seu L'art du Japonais au vingtième siècle, a arte japonesa desde sua origem caracteriza-se por duas especificidades: "uma maneira emocional de ver que repousa sobre uma percepção do mundo viva e em movimento" e "uma maneira espontânea de apreender o que existe verdadeiramente".

Haruo Ohara não parece indiferente a esta regra. O que surpreende no fotógrafo nipô-londrinense é que, diferentemente do que se via sendo produzido na arte fotográfica de seu tempo, ele opera um intenso trabalho de desconstrução tanto da concepção de verdade expressa por meio da mimese quanto da suposta autonomia do referente nesse tipo de imagem, criando assim fotografias que são como superfícies e envelopes. A fotografia torna-se uma espécie de tela protetora que, ao mesmo tempo, separa e aproxima o espectador da cena. Para apreender os momentos de silenciosa intensidade dessas composições inexpressivas de que se originam suas fotografias, é preciso, diante delas, sonhar e meditar. É como se Ohara retivesse em suas imagens o impacto dos objetos, sua presença, e não seu sentido.

Ohara, por meio do seu olhar fotográfico, descobre uma maneira de literalmente descolar o sentido como uma pele sobre o real, pois o que parece contar nas suas fotografias não é a expressão do autor, seu papel - afinal, a contraluz intensa frequentemente aí empregada quebra qualquer tentativa de uma leitura nessa direção -, mas a própria expressão do gesto em si.

Assim, as representações não têm, forçosamente, correspondência com a realidade representada. Aliás, cabe lembrar que, para o Oriente, notadamente a arte zen, todo o trabalho de combinação, composição e formas, longe de ser puro e simples artificialmente, como olhos ocidentais insistem em vê-lo, representa um caminho na direção do mundo espiritual esteticamente perfeito. Pois, ao fazer "cria-se e não obedece a uma intenção", nota ainda Francisco Handa (1991, p. 79).

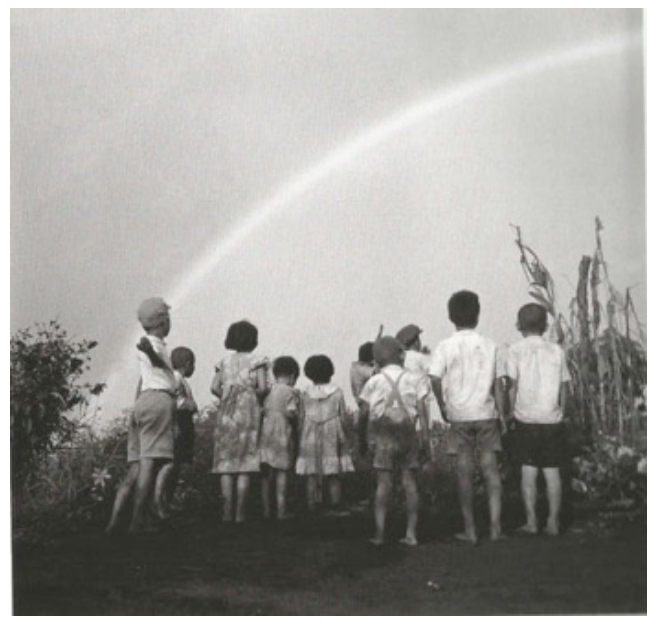

Fig. 3. Crianças apreciando arco-íris Fonte: Instituto Moreira Salles 


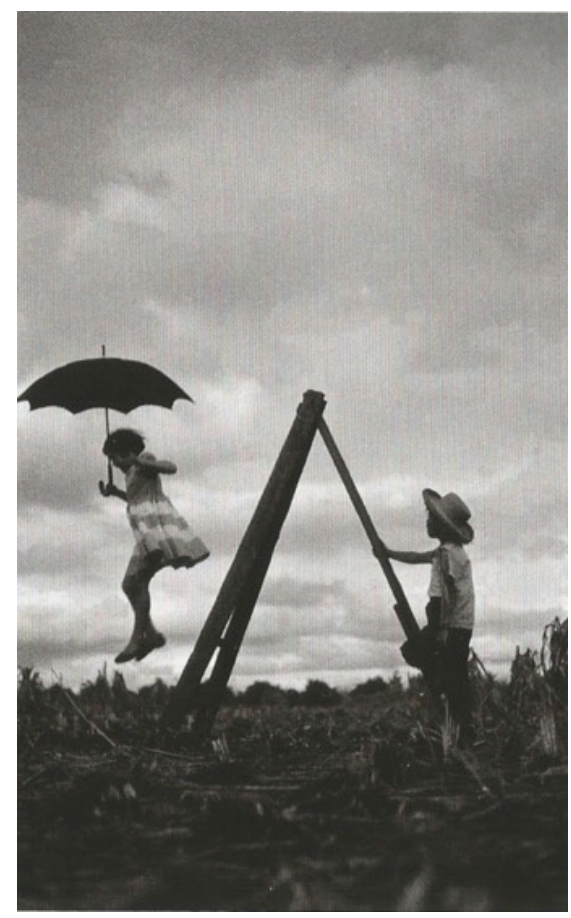

Fig. 4. Filha Maria saltando e sobrinha Maria Tomita Fonte: Instituto Moreira Salles

Não é que as formas da arte zen sejam deixadas de lado, mas se encontra nelas uma ausência ideal de forma, uma espécie de distanciamento em sua enunciação que produz estranhamente um "vazio de fala". Esse esvaziamento advém do gesto do artista que fotografa como se não estivesse fotografando. Mostra-se não como um agente que externamente interfere, ao contrário, é como se agisse sem nenhuma intenção, sem nenhum esforço, levando a imagem a uma estranha e insuspeita situação de suspensão do sentido ao revelar ao espectador um mundo em sua significância.

Não se quer com isso dizer que as fotografias de Haruo Ohara não tenham nenhuma significação, mas, tal como num poema japonês, o haikai, ela não é mais que um aceno breve que faz apenas cintilar o sentido². Como fotógrafo-poeta, Ohara realiza aquilo mesmo que faz o poeta haikaista: ele não descreve o que pensa, muito menos o que sente. Suas fotos conduzem o espectador a captar a sensação por meio de "uma ilusão ao indizível" ou, para que seja mantido o paradigma da visão, "uma ilusão ao invisível". O invisível não é - na concepção de Merleau-Ponty - aquilo que está para além do visível,

2 Não avanço nesta relação entre fotografia e haikai, pois já a fiz em outro trabalho. Basta, aqui, lembrar que ambas as artes se caracterizam pelo irrepetível, pela impossibilidade de serem traduzidas. Uma fotografia ou um haikai são gestos únicos irredutíveis, cujas possibilidades de significar são inesgotáveis, dependendo simplesmente da mente que o lê ou vê. 
ao contrário, é simplesmente aquilo que não se consegue ver ou, nas palavras de Marilena Chauí (1981, p. 257), em Da realidade sem mistério ao mistério do mundo, "coextensivo ao visível, o invisível não é uma outra ordem de realidade, mas o forro que atapeta o visível".

O poeta oriental percebe a grandeza nas mais pequeninas coisas da vida cotidiana, na haste de uma relva, por exemplo. Limitado a contemplá-la, "sente o que quer que seja no espírito, mas não o expressa [...] seu sentimento é tão pleno e tão profundo que não sente o desejo de conceituá-lo", nota Susuki (1960, p. 12), comparando Oriente e Ocidente. E então, a esta nota, acrescenta o filósofo: "embriagado por esse sentimento, [o poeta] exclama, e sua exclamação é um grito indizível, inaudível".

Penso nesta instigante foto de 1948 intitulada "Céu de inverno (vento frio)". Como em todo haikai, há a menção a uma determinada estação do ano que evoca toda a emoção a ela associada. Uma espécie de quietude e de calma emanam dessa imagem, que parece não pretender outra coisa senão deixar o espectador respirar e sentir o suflo do próprio vento.

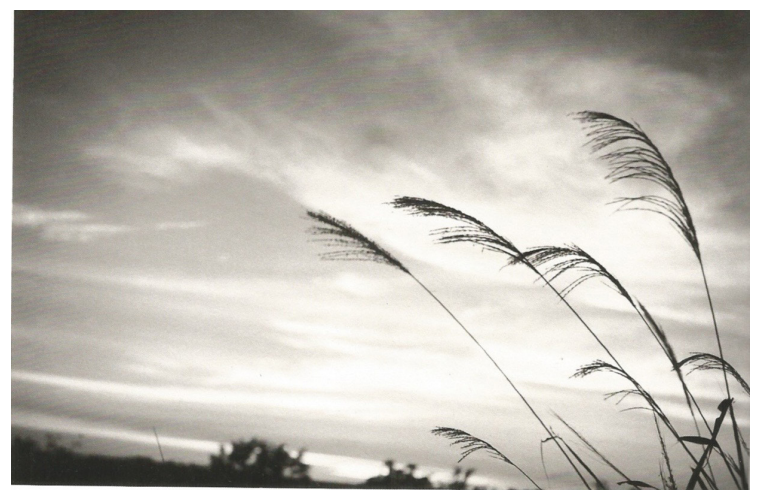

Fig. 5. Céu de inverno (vento frio) Fonte: Instituto Moreira Salles

Para não nos distanciarmos demasiadamente do Ocidente e não cairmos numa espécie de abstracionismo conceitual, pode-se acreditar que, em certo aspecto, o gesto fotográfico de Haruo Ohara se alinha a uma concepção de imagem que é muito mais da ordem da impressão do que da descrição. É como se as coisas, as cenas, se constituíssem fotograficamente diante de seus olhos: verdadeiras emanações sem nenhuma vibração, não exprimem, fazem simplesmente existir. Trata-se de uma aventura do olhar em que algo advém, que é ínfimo, miúdo, e que é capturado em seu surgimento neutro antes mesmo que se perca outra vez na desordem do mundo. São fotografias que não visam a aprisionar os instantes na sua dimensão de grandeza, mas aparições de essência frágil que apontam o surgimento do mundo em sua imediaticidade.

É como se o olhar de Ohara atravessasse a carapaça do instituído, desnudando o originário de um mundo visível para entregar aos olhos do espectador uma experiência 
do olhar que, em perspectiva merleau-pontyana, nasce de "um visível [que] se faz vidente sem sair da sua visibilidade", escreve Marilena Chauí (1981, p. 272) em Da realidade sem mistérios, ao mistério do mundo. Noutras palavras, é como se o fotógrafo se sentisse visto pelas coisas enquanto as vê para enquadrá-las.

Mesmo correndo o risco de ocidentalizar demais essa concepção oriental, as imagens de Haruo Ohara acenam para o momento do encontro simultâneo entre decisão e ação. É o que assinala o professor de literatura e artes da Université de Rennes 2, Hautes Bretagne, Jean-Pierre Montier (2007, p. 202), em sua biografia intelectual de Cartier Bresson intitulada Art sans Art, ao explorar a metáfora do fruto maduro que se desprende da árvore para explicar em parte a parte o gesto fotográfico de Bresson: "esse instante crítico é também realização, na condição de que, entretanto, ela obedeça a uma lógica interna, conjuntamente àquela da árvore e do fruto, e não a uma lógica imposta por uma vontade exterior". A criação artística zen - nota ainda Montier (ibidem, p. 210-211) é "instantânea e não retocável, o sujeito sendo definido pela sua postura de apagamento e de fusão no processo conjunto com aquilo que ele faz corpo". Uma expressão artística despossuída de todo espírito de intenção, um despertar "mais uma forma de plenitude sem objetivo do que um êxtase místico" (ibidem, p. 211).

\section{Técnica interior}

Portanto, a estética zen aproxima - pode-se ousar pensar - aquilo que a arte ocidental etiqueta de arte "minimalista". É, no entanto, um minimalismo que não se confunde com o minimal art, surgido nos anos de 1960 em oposição ao expressionismo abstrato. É toda uma outra definição que entra em cena. Trata-se de arte que visa a incentivar e preferir a transmissão de uma sensação em detrimento de uma mensagem. $\mathrm{O}$ traço mínimo não é isento de significação, pois ele advém num contexto preparado. O espaço torna-se estético por intervenção humana, mas de maneira leve, sem pompa, quase sem barulho.

Pode-se pensar que, no limite, o ato fotográfico de Haruo Ohara se alinha à noção de fotografia inexpressiva ou fotografia neutra proposta pela crítica e curadora britânica Charlotte Cotton (2013, p. 81), em A fotografia como arte contemporânea. Uma fotografia que se caracteriza por um "aparente distanciamento emocional e autocontrole do fotógrafo", permitindo à imagem fotográfica "ultrapassar o hiperbólico, o sentimental, o subjetivo", nota a autora.

Ao entrever aí um descarte de qualquer idealização da forma, da aparência ou fisionomia em detrimento de uma representação de pureza espiritual, o olhar de Haruo Ohara cruza com o olhar do poeta, com tudo aquilo que a esse olhar é solicitado para ver as coisas como são, e não para transformá-las em símbolos ou expressões de outra coisa mais. Eis aí uma das razões para denominá-lo de fotógrafo-poeta.

A fotografia, como essa imagem técnica de exterior (feita por um aparelho), nas mãos e por meio dos olhos de Ohara, torna-se uma técnica interior que, por sua vez, não tem 
a ver com a simples habilidade do fotógrafo, mas resulta de um processo que acontece no âmago mesmo do artista. A arte fotográfica torna-se zen quando surge da "não mente", uma condição de "sem eu", "sem ego" (em japonês mu-ga), que assume a forma de um ato expressivo não mediado. Trata-se de uma arte sem arte, uma arte da alma.

A arte fotográfica inspirada no zen caracteriza-se por um esperar, não do "instante decisivo" de Cartier Bresson - não há um instante pregnante em Ohara -, mas da justaposição harmoniosa de diferentes elementos heterogêneos a tal ponto da concentração que se eleva ao aniquilamento de si (silencia o eu interior) para mergulhar na cena a fim de sentir, viver e capturá-la em sua plenitude. São como "momentos de intensidade" para evocar uma expressão de Hans Grumbrecht (2010, p. 127) -, que não produzem "nenhuma mensagem". O que se dá a ver não é a expressão do fotógrafo em relação ao que ele exprime (isso é sua interpretação); vê-se aí apenas a expressão, que surge como isenta da mão do artista.

É preciso evocar aqui esta outra foto, "Dona Kô (esposa)", no lago de Igapó em Londrina. Num gesto fotográfico numa espécie de plongée, Haruo Ohara fotografa sua esposa pescando de pé sobre uma pedra à beira do lago, tudo isso tomado num distanciamento que parece não pretender buscar o "coração romântico" da cena fotografada tampouco da paisagem. Ambas revelam-se austeras e neutras.

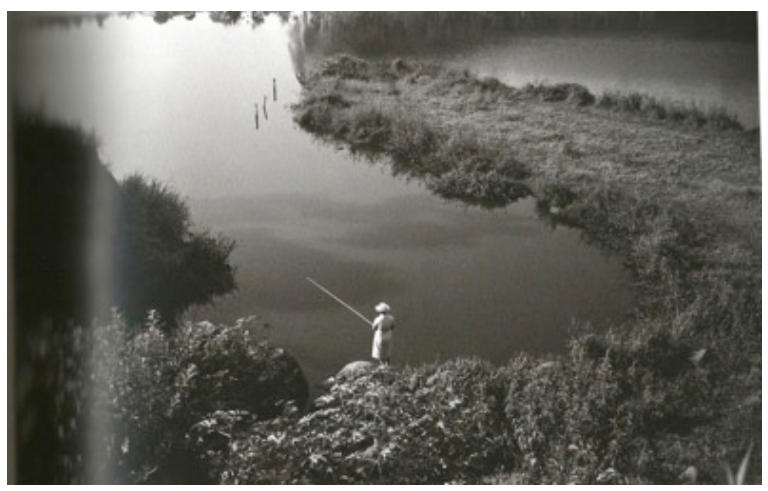

Fig. 6. Dona Kô (esposa), lago Igapó. Fonte: Instituto Moreira Salles

A luz é outro objeto digno de nota nas fotos de Haruo Ohara. Observando a inscrição e o tracejar da luz em suas fotografias, somos levados a notar que seu uso está em plena oposição àquele feito, por exemplo, por um Sebastião Salgado, que, para realçar o lirismo de suas fotos, explora à maneira de um expressionista uma composição de contraluz rica em matizes e gestos dramatizados concebidos a partir das várias nuances de preto e branco. Já em Ohara, com seu estilo bastante acético, essa mesma contraluz, esse jogo de luz e sombra - aliás, toda sua reverência à sombra é algo notável - faz surgir um princípio 
de naturalidade zen, um nada de nada, nada especial que se refere a estado de coisas expresso em sua naturalidade, já que seu olhar contenta-se em mostrar apenas coisas que acontecem no cotidiano em vez do drama. Essa contraluz dá visibilidade a uma espécie de cinza, de vapor, de névoa que constituem um véu indistinto colocado diante das coisas.

Longe de ser um convite à espera pela dissipação da bruma, da névoa, sua fotografia pode ser compreendida, ao contrário, como um mergulho em sua nebulosidade para daí olhar o jamais visto, o não-visto, um visível que nem sempre é claro e distinto. Trata-se de uma espécie de branco bem concebido que, nas películas de Ohara, ganha uma potência de emoção bastante forte. Essas cenas fotográficas constituídas de poeiras luminosas estão longe de ser abstratas, são perturbadoras. Ao gerarem uma indiscernibilidade entre céu e terra, evidenciam a possibilidade de visão: a suspensão do mundo torna-se visível. As nuvens, os raios do pôr-do-sol, a agitação das folhas pelo vento mostram cada vez menos e querem deixar ver cada vez mais. É como se filtrassem a graça; como se deixassem a luz falar e não o contrário, a fizessem falar por meio de sua lente.

A exemplo disso, não é possível deixar de mencionar as seguintes fotos: 1948, "Nuvens", e essas outras duas captadas em 1953 e intituladas "Paisagens captadas na Chácara Tomito" em Lodrina.

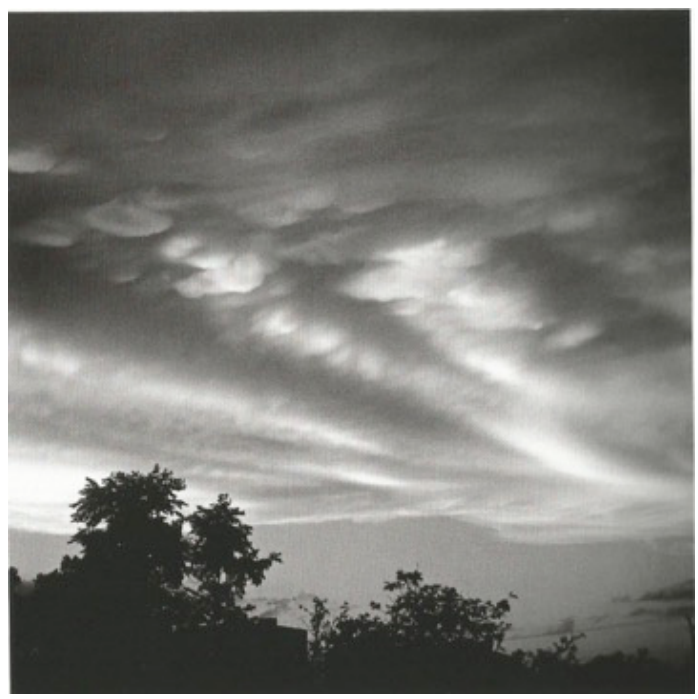

Fig. 7. Nuvens

Fonte: Instituto Moreira Salles 


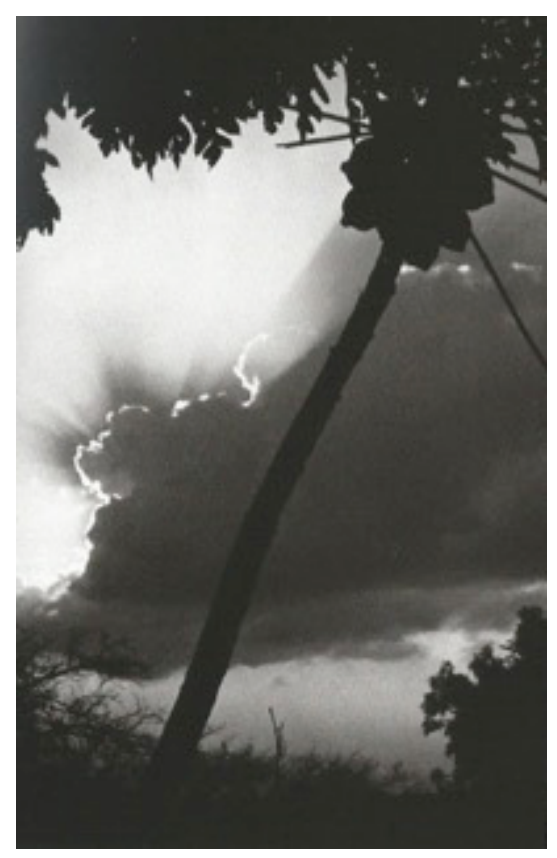

Fig. 8. Paisagem captada na chácara Tomita. Fonte: Instituto Moreira Salles

E então, nesses instantes, é que o olho dá lugar à vidência, que se passa do olho para a visão. O vidente é aquele que enxerga, no visível, sinais invisíveis aos olhos profanos. Mas, afinal, a que remete a visão do visionário, do vidente? A resposta: ao visual.

O visual - nota George Didi-Huberman (2013) em Diante da imagem - é a qualidade especial do visível que só se revela em imagens muito raras. Não se refere à aparência das imagens. O visual é esse inesperado desvelamento do olhar que toma o espectador de assalto, fazendo emergir uma emoção por meio de uma aparição frágil e instável de ser e coisa na superfície luminosa do fotográfico, que, misteriosamente, torna presente aquilo que até então era meramente visível. Uma espécie de epifania imprevisível: instante em que a poética das coisas se revela e, então, a obra extravasa seu sentido primeiro, dando lugar, de uma maneira ou de outra, ao suplemento de sentido. Esses momentos de epifania não se definem por sua beleza, mas por serem discretos, fortuitos como também de plenitude.

Instante de paisagem em que se percebe ou se reconhece (faz ver), na paisagem do cotidiano, uma espécie de aparição, como se algo inesperado surgisse diante de nossos olhos, como se a cada experiência fotográfica o instante clicado repentinamente ganhasse relevo e se elevasse aos olhos do espectador. Em tais momentos, aquilo que foi fotografado (aquela pessoa, aquele céu, aquela árvore) torna-se efetivamente coisas que respiram nesta terra e, por força poética do olhar do fotógrafo, essa sensação de vida é miraculosamente capaz de chegar até o espectador. 
Essa qualidade de passagem miraculosa da visualidade em visual não se refere a uma qualidade do dispositivo fotográfico ou mesmo da fotogenia. É uma misteriosa qualidade que se manifesta entre a postura do fotógrafo e o olhar da câmera. Entre a "técnica exterior" do aparelho e a "técnica interior" do artista. O fotógrafo, num ato único, soube esperar para "ver" e "capturar" as inesperadas aparições do visual no visível, mas também driblar a mimese tradicional e a perspetiva próprias da "técnica exterior", fazendo aparecer em suas fotos as matrizes estéticas próprias do olho japonês.

Penso nesta instigante foto de 1953, "Araucárias perto de Mauá da Serra": o tom acinzentado da imagem, que toma as árvores num primeiro plano e esvazia toda cena com um fundo ligeiramente desfocado por efeito da luz e do jogo de foco, inscrevendo a presença e o respiro da vegetação no quadrante fotográfico.

Portanto, por meio de certas fotos de Ohara, passa-se - para usar uma expressão de Hans Gumbrecht (2010, p. 132) - de uma cultura do sentido para a cultura da presença, quando nas situações rotineiras "o súbito aparecimento de certos objetos de percepção desvia nossa atenção", fazendo com que "a natureza se transforme em acontecimento".

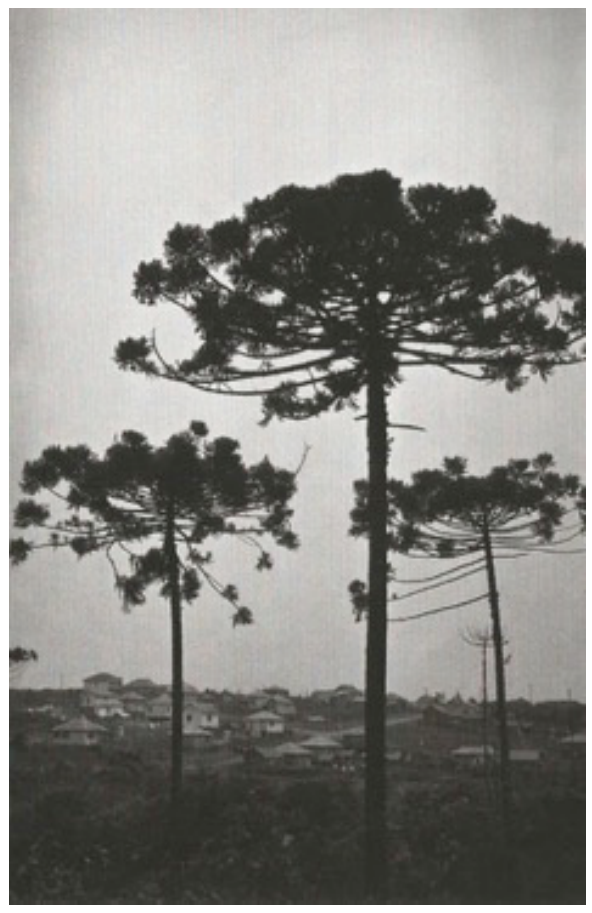

Fig. 9. Araucárias perto de Mauá da Serra. Fonte: Instituto Moreira Salles. 


\section{Técnica exterior}

Examinando mais de perto o trabalho de enquadramento fotográfico de Haruo Ohara, a primeira coisa perceptível em sua técnica de exterior e que acena para o estado de espírito zen é a total simplicidade de sua técnica com a câmera, que é a mais despojada possível. Sem temer, traz para suas fotos aquele mesmo plano eternizado pelas mãos do cineasta japonês Yasujiro Ozu e denominado por alguns teóricos do cinema - como Gilles Deleuze (2007) em Cinema 2 - de "plano tatami". Arrisco talvez a pensar que tal disposição de câmera se justifica por ser o mesmo ponto de vista de um japonês sentado no tatami, ou ainda de um monge zen que medita. Para além da semelhança entre os planos, não se pode esquecer que a obra do cineasta e a do fotógrafo se assemelham, de certo modo, também pelo objeto, que, para Deleuze (ibidem, p. 23), caracteriza-se pela "banalidade cotidiana apreendida como vida de família".

A maioria das suas fotografias é assim marcada por uma objetiva que não se quer evasiva, que escarafuncha a coisa a ser representada a tal ponto de atingir o seu coração romântico, mas se põe sempre num distanciamento como que desativando ou contendo a mola dramática da cena fotografada. Assim, as fotografias de Haruo Ohara arrancam dos clichês verdadeiras imagens.

Impossível não pensar nesta fotografia de 1952, "Nuvem da manhã", em Terra Boa - Paraná, ou ainda nesta outra não menos artisticamente instigante de 1957, "Estrada de Ferro - arredores de Londrina". A câmera baixa e levemente inclinada, como se estivesse a fazer uma contre plongée, cria um cenário chapado da cena, que quebra qualquer ilusão de perspectiva e, inesperadamente, o olhar do espectador é assombrado pelo vórtice vertiginoso que a dimensão expandida do céu ganha no quadrante fotográfico.

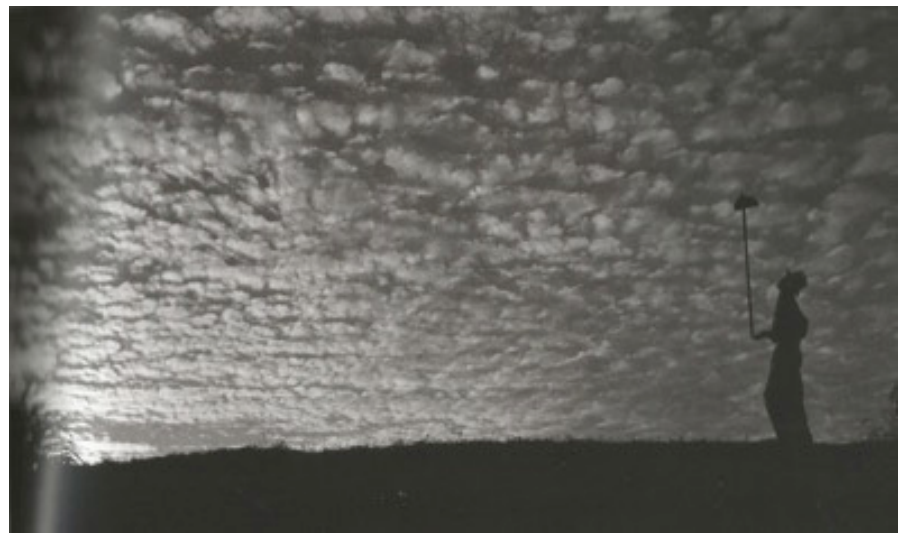

Fig. 10. Autorretrato - "Nuvem da manhã". Fonte: Instituto Moreira Salles 


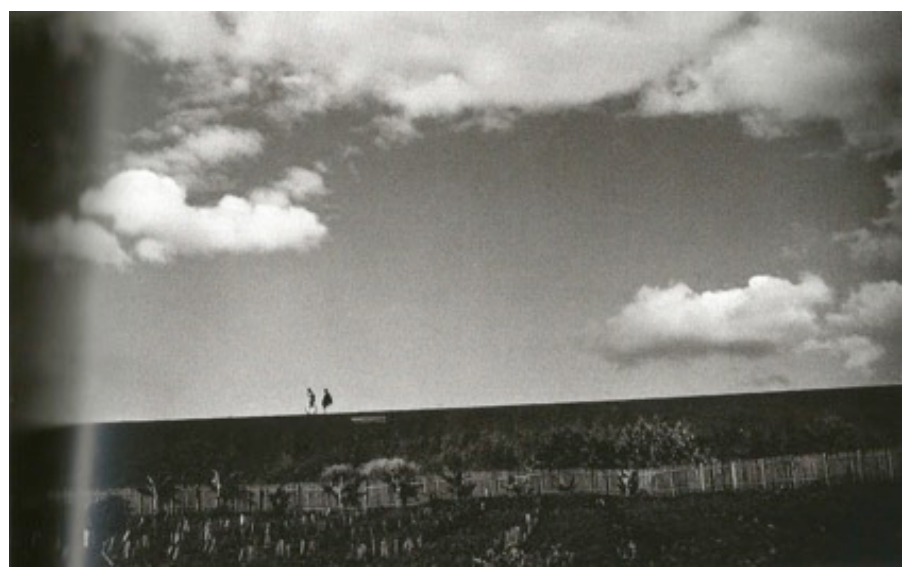

Fig. 11. Estrada de ferro - arredores de Londrina. Fonte: Instituto Moreira Salles

Constrói-se, assim, uma fotografia fria que posiciona o espectador de forma distanciada e desengajada. Se suas fotos nos dão a impressão de que os homens e as coisas se mostram tais como eles são em si, é porque os dispositivos fílmicos são paradoxalmente arbitrários e sem origem. Ohara, num golpe inesperado de sofisticação fotográfica, cria um tipo de "enunciação" que diz: "eis aqui", mas um "eis aqui" que não remeteria, como em tantos outros fotógrafos, à autoridade do mostrador, ao sujeito na enunciação que elegeu o "isso em questão" (eu escolhi mostrar isso), nem mesmo de um destinatário subjugado. Suas imagens fotográficas dão provas de uma estranha forma de enunciação, de uma enunciação sem autor, de um olhar sem sujeito, de uma presença concreta criada por uma enunciação vazia, em que pouco importa o que significa cada uma dessas fotos, o que elas apontam é o trabalho de significação: a vocação de sentido ou o apelo ao sentido.

Ohara cria em suas fotos verdadeiros espaços vazios - exteriores ou interiores vazios de acontecimentos e personagens. Esses espaços vazios são autônomos e atestam um estado de pura contemplação e, ao mesmo tempo, acenam com uma forte suspensão de toda temporalidade. A imagem fotográfica torna-se uma imagem cristal, um "jorro do tempo" (DELEUZE, 2007, p. 87), que se constitui num circuito entre uma imagem atual e uma imagem virtual que são tanto distintas quanto indiscerníveis.

Os espaços vazios se dividem em espaços ou paisagens vazias e naturezas-mortas, como nesta fotografia de 1958, "BR 369 - Rodovia Melo Peixoto", arredores de Londrina, Paraná. Uma longa trilha se inscreve de um canto e esmaece ao fundo, algumas construções, placas e um único carro que vai rumo à infinitude do plano, nenhuma outra marca de presença, tudo converge para um horizonte esvaziado. A natureza morta se define pela presença de objetos que se tornam seus próprios envelopes: é a imagem do pequeno "Açucareiro de alumínio" de 1948. O olhar do fotógrafo se entrega à superfície 
das coisas, rendendo fotografias que captam um mundo mudo, puramente fenomenal: algo de mais material e opaco. Se é possível aproximar as fotografias de Ohara à fotografia de arte, é porque, a princípio, elas se voltam às temáticas consagradas pela tradição pictórica: a paisagem e a natureza morta.

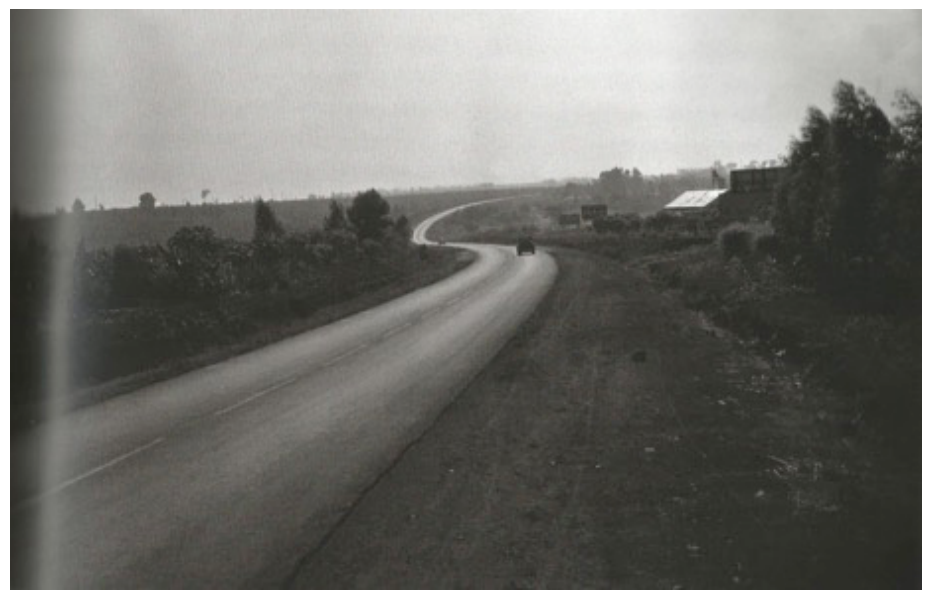

Fig.12. BR 369 - Rod. Melo Peixoto Fonte: Instituto Moreira Salles

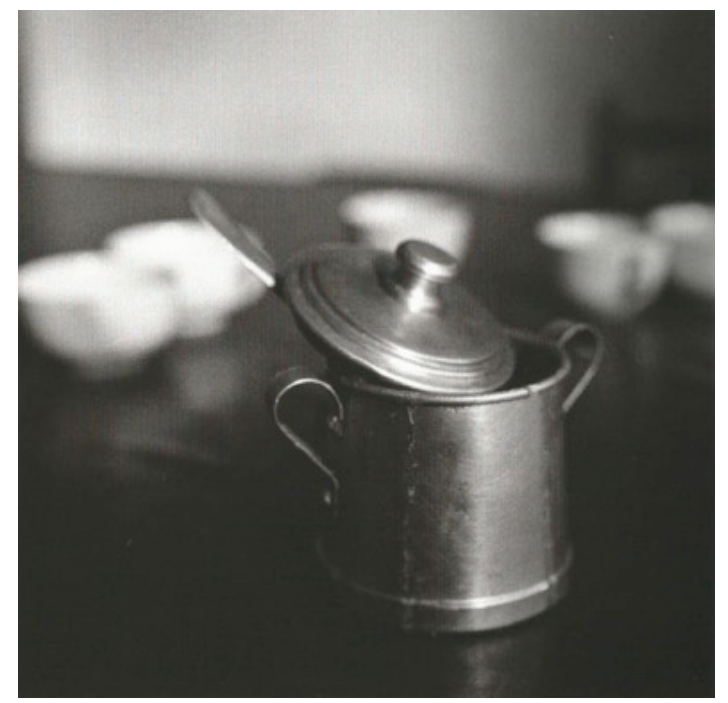

Fig. 13. Açucareiro de alumínio Fonte: Instituto Moreira Salles

Essas imagens são puras e diretas do tempo. Representam o tempo e a sua duração. Essa duração é precisamente a representação daquilo que permanece através da sucessão 
dos estados mutantes. Cada foto é o tempo e cada uma delas revela, sob tais e tais condições, o que muda no tempo. Noutras palavras, sua fotografia designa o tempo como forma inalterada preenchida pela mudança.

A beleza de certas fotos de Ohara está no que nelas é resto, naquilo que se passa no "entre" tempo, nas esperas, no tempo morto, naqueles momentos em que nada acontece, nas brumas, em que o fotógrafo faz ver, num instante, aquilo que permanece, o tempo, e aquilo que é efêmero: as coisas em sua qualidade evanescente.

Assim, a arte zen de Ohara aproxima suas imagens da "estética do vazio" proposta na obra de Barthes (2003), com tudo que sua concepção de vazio retém da própria noção de neutro barthesiano, que, é preciso assinalar, não tem a mesma perspectiva de leitura proposta por Charlotte Cotton já mencionada anteriormente, mas guarda uma outra direção teórica que joga com a possibilidade de ver certas imagens como "furta-cores", ou seja, fazer da imagem um "espaço totalmente e como que exaustivamente matizado". E por isso mesmo, a imagem torna-se esse espaço que "muda sutilmente de aspecto, talvez de sentido, segundo a inclinação do olhar do sujeito", escreve Roland Barthes (2003, p. 109), em $O$ Neutro. Ou melhor, o Neutro barthesiano caracteriza-se por uma espécie de utopia da linguagem sem marcas ou, ainda, de certo modo, corresponde ao gesto suspensivo da linguagem, o que Jean Pierre-Richard (2006, p. 17), em seu Roland Barthes, dernier paysage, denominou de "o grau zero da presença". Trata-se, portanto, de uma estética que joga, dentre outras, com a possibilidade de entrever um signo vazio, marcado pelo fracasso mesmo a dar ou fabricar sentido, colocando em colapso a própria máquina semiótica ${ }^{3}$.

Alguns olham as fotos de Ohara e não veem nada, enquanto outros se abrem ao invisível, ao visual. Afinal, suas fotos não emolduram nada, elas são emolduradas de vazio. E, nesse ponto, aquela foto "Céu de inverno (vento frio)" de 1948 é exemplar, é como se respirássemos o tempo com todo frescor do momento do fotografado. Nada a ver - repete-se-, ela não emoldura nada, ao contrário, ela é emoldurada de vazio.

Rodrigo Fontanari é pós-doutorando no Programa de Pós-graduação em Multimeios da Universidade Estadual de Campinas.

fontanari.rodrigo@yahoo.fr

\section{Referências}

BARTHES, R. O império dos signos. Tradução de Leyla Perrone-Moisés. São Paulo: Martins Fontes, 2007. O neutro. Tradução de Ivone Castilho Benedetti. São Paulo: Martins Fontes, 2003.

3 Retenho-me a estas notas a respeito desta noção barthesiana de "estética do vazio", pois toda essa complexa relação, que conduz ao fosco da linguagem, foi anteriormente desenvolvida num artigo em curso de edição na revista Alea-Estudos Neolatinos. 
BONI, P. A fotografia como mídia visual da recuperação histórica de Londrina. In: Intercom Sociedade Brasileira de Estudos Interdisciplinares de Comunicação. V Congresso Nacional de História da Mídia. São Paulo, 2007.

COTTON, C. A fotografia como arte contemporânea. Tradução de Maria Silvia Mourão Netto; Marcelo Brandão Cipolla. São Paulo: Wmf Martins Fontes, 2013.

CORREA, M. S. C. "A fração de segundo e a história", In: BURGI, S. (Org.). Haruo Ohara: fotografias. São Paulo: Sesi/IMS, 2008.

CHAUÍ, M. Da realidade sem mistérios ao mistério do mundo (Espinosa, Voltaire, Merleau-Ponty). São Paulo: Brasiliense, 1981.

DELEUZE, G. Cinema 2. Imagem-tempo. Tradução de Eloisa de Araujo Ribeiro; revisão filosófica de Renato Janine Ribeiro. São Paulo: Brasiliense, 2007.

DIDI-HUBERMAN, G. Diante da imagem: questão locada aos fins de uma história da arte. Tradução de Paulo Neves. São Paulo: Ed. 34, 2013.

GUMBRECHT, H. U. Produção de presença: o que o sentido não consegue transmitir. Tradução de Ana Isabel Soare; apresentação de Marcelo Jasmin. Rio de Janeiro: Contraponto, 2010.

HANDA, F. O que é zen. Coleção Primeiros Passos. São Paulo: Brasiliense, 1991.

HERRIGEL, E. A arte cavalheiresca do arqueiro zen. Préfácio do Prof. D. T. Suzuki. Tradução, prefácio e notas de J. C. Ismael. São Paulo: Editora Pensamento, 1983.

HUMPHREYS, C. O zen-budismo. Tradução de Louisa Ibañez. Rio de Janeiro: Zahar, 1977.

KOELLREUTTER, H. À procura de um mundo sem "vis-à-vis": reflexões estéticas em torno das artes oriental e ocidental. São Paulo: Novas Metas, 1984.

LOSNAK, M.; IVANO, R. Lavrador de imagens: uma biografia de Haruo Ohara. Londrina: S. H. Ohara, 2003.

LUCKEN, M. L'art du Japon au vingtième siècle. Pensée, formes, résistences. Paris: Hermann, 2001.

MONTIER, J. L'art sans art. Henri Cartier-Bresson. Paris: Flammarion, 2007.

RICHARD, J. Roland Barthes, dernier paysage. Paris: Editons Verdier, 2006.

SUZUKI, D.T. Introdução ao zen-budismo. Tradução e apresentação de Murillo Nunes de Azevedo. Rio de Janeiro: Editora Civilização Brasileira, 1971.

Zen-budismo e psicanálise. Tradução de Octavio Mendes Cajado. São Paulo: Cultrix, 1970.

TRUNGPA, C. Pratique de la voie tibétaine. Au-delà du matérialisme spirituel. Traduit de l'américain par Vicent Bardet. Paris: Seuil, 1976. 